\title{
Occupational risk factors of lung cancer in a French case-control study
}

\author{
SIMONE BENHAMOU,' ELLEN BENHAMOU, ${ }^{2}$ R FLAMANT ${ }^{12}$ \\ From the Unité de Recherches en Epidémiologie des Cancers (U287),' INSERM, and Département de \\ Statistique Médicale, ${ }^{2}$ Institut Gustave Roussy, Villejuif, France
}

ABSTRACT A case-control study of 1625 histologically confirmed cases of lung cancer and 3091 controls matched for sex, age, hospital admission, and interviewer was conducted in France between 1976 and 1980. The results presented concern the effects of different occupations on the occurrence of lung cancer among 1334 male cases and 2409 matched controls. Occupations were coded blindly according to the International Standard Classification of Occupations. An excess risk of lung cancer was observed for the following occupations after adjustment for cigarette exposure: farmers $(R R=1.24, p<0.06)$, miners and quarrymen $(R R=2.14, p<0.02)$, plumbers and pipe fitters $(R R=1 \cdot 80, p<0.04)$, motor vehicle drivers $(R R=1.42, p<0.01)$.

With present knowledge, it is difficult to make any precise estimate of the proportion of cancers attributable to occupation. For lung cancer, smoking habits have to be taken into account since the prevalence of cigarette smoking varies with occupational status. This was seen illustrated in France' ${ }^{1}$ and in England. ${ }^{2}$ A close association between average smoking habits for each occupational order and lung cancer mortality has been described. ${ }^{2}$ Doll and Peto attributed $15 \%$ of male and $5 \%$ of female cases of lung cancer in the United States to occupational factors. ${ }^{3}$

At present several occupations are recognised by the International Agency for Research on Cancer (IARC) to have an increased risk of lung cancer causally related to the occupation, ${ }^{45}$ those affected include some subgroups of the following occupations: agriculture, forestry and fishing, asbestos production, metal industry, shipbuilding, chemical industry, pesticide and herbicide production, extractive occupations, gas industry, and construction industry. Moreover, an increased risk of lung cancer was reported for other subgroups among these occupations but for which the assessment of the causal relation with the occupation was not definitive.

The results here concern occupations already known or suspected to be associated with lung cancer in France. They have been taken from an international case-control study performed to study smoking habits.

Accepted 6 April 1987

\section{Material and methods}

A complete description of the study may be found in previous reports. ${ }^{67}$ In France 1625 cases with histologically confirmed lung cancer and 3091 controls whose current diseases were not related to tobacco were included between 1976 and 1980. Each case was matched with one or two controls on sex, age at diagnosis ( \pm 5 years), hospital of admission, and interviewer. The questionnaire included questions about place of residence since birth, educational level, occupation, and smoking and drinking habits. A complete occupational history was recorded. Respondents were asked to give their occupations, from the most recent to the first, with the corresponding duration (at least one year). These data were previously coded according to chemical or physical exposures determined by a panel of experts, such as coal dust, gasoline, or asbestos. The data were recoded blindly using the International Standard Classification of Occupations. ${ }^{8}$

Since most women had no occupation, and since few men smoked cigars and pipes, these categories were excluded and the results limited to male non-smokers or exclusively cigarette smokers. All the analyses were performed with adjustment for cigarette status. The effect of each occupational exposure was estimated by a matched logistic regression ${ }^{9}$ taking into account cigarette exposure defined by age at the first cigarette (non-smokers, 20 years or more, less than 20 years), daily consumption of cigarettes (non-smokers, less than 20 cigarettes a day, and 20 cigarettes or more a 
day), and duration of cigarette smoking (nonsmokers, less than 35 years, and 35 years or more).

\section{Results}

For each model, 1260 strata composed of 1260 cases and 2084 matched controls have been considered. The 254 other strata had to be excluded because either the case or the matched controls did not satisfy the required criteria (non-smokers or exclusively cigarette smokers). For each occupation of interest, the baseline category was composed of patients who had never been engaged in that particular occupation.

Table 1 shows the matched RR of lung cancer for major groups of occupations, adjusted for cigarette exposure. The risk of lung cancer was significantly lower for the following groups: "professional, technical, and related workers" $(\mathrm{RR}=0.59, \mathrm{p}<0.0005)$ and "administrative and managerial workers" $(R R=$ $0.68, p<0.02)$. By contrast, the $R R$ was significantly higher for "production and related workers, transport equipment operators, and labourers" $(R R=1 \cdot 24$, $\mathrm{p}<0.008$ ). An excess risk of borderline significance, was found for "agricultural, animal husbandry and forestry workers, fishermen, and hunters" (RR = $1.22, \mathrm{p}<0.07)$. A more detailed analysis was performed among the two groups for which an excess risk was found. As this study was mainly performed to study tobacco, only occupations known or suspected to be related to lung cancer were considered (table 2). Moreover, relative risks were calculated for occupations including at least 10 cases or controls, or both.

A significant, or borderline significant, excess risk of lung cancer was found for farmers $(R R=1 \cdot 24$, $\mathrm{p}<0.06)$, miners and quarrymen $(R R=2 \cdot 14$, $\mathrm{p}<0.02)$, plumbers and pipe fitters $(R R=1.80$, $\mathrm{p}<0.04)$, sheet metal workers $(\mathrm{RR}=1.51, \mathrm{p}<0.08)$, and motor vehicle drivers $(R R=1.42, p<0.01)$. There was no evidence of an increase in risk with duration of exposure. No significant interaction with smoking status was found in any of the occupations studied.

Table 1 Adjusted matched RR of male lung cancer for major groups of occupations (International Standard Classification of Occupations)

\begin{tabular}{|c|c|c|c|c|}
\hline & $\begin{array}{l}\text { No of } \\
\text { cases }\end{array}$ & $\begin{array}{l}\text { No of } \\
\text { controls }\end{array}$ & $\begin{array}{l}\text { Adjusted matched } R R^{*} \\
(95 \% C I)\end{array}$ & $p$ \\
\hline $\begin{array}{l}\text { Professional, technical, and related workers } \\
(011-199) \\
\text { Administrative and managerial workers }\end{array}$ & 82 & 236 & $0.59(0.43-0.81)$ & 0.0005 \\
\hline $\begin{array}{l}\text { Clerical and related workers (300-399) } \\
\text { Sales workers }(400-490) \\
\text { Service workers }(500-599) \\
\text { Agricultural, animal husbandry, and forestry } \\
\text { workers, fishermen, and hunters }(600-649)\end{array}$ & $\begin{array}{r}63 \\
249 \\
116 \\
122 \\
151\end{array}$ & $\begin{array}{l}140 \\
420 \\
192 \\
208 \\
246\end{array}$ & $\begin{array}{l}0.68(0.48-0.97) \\
0.89(0.72-1.09) \\
0.94(0.70-1.24) \\
1.01(0.77-1.33) \\
1.22(0.94-1.59)\end{array}$ & $\begin{array}{l}0.02 \\
\text { NS } \\
\text { NS } \\
\text { NS } \\
0.07\end{array}$ \\
\hline $\begin{array}{l}\text { Production and related workers, transport } \\
\text { equipment operators, and labourers (700-999 }\end{array}$ & 843 & 1260 & $1.24(1.04-1.47)$ & 0.008 \\
\hline
\end{tabular}

*Adjusted for cigarette exposure.

Table 2 Adjusted matched RR of male lung cancer for some occupations (International Standard Classification of Occupations)

\begin{tabular}{|c|c|c|c|c|}
\hline & $\begin{array}{l}\text { No of } \\
\text { cases }\end{array}$ & $\begin{array}{l}\text { No of } \\
\text { controls }\end{array}$ & $\begin{array}{l}\text { Adjusted matched } R R^{*} \\
(95 \% C I)\end{array}$ & $p$ \\
\hline $\begin{array}{l}\text { Farmers (611-629) } \\
\text { Miners, quarrymen (711) } \\
\text { Machinery fitters, machine assemblers, } \\
\text { precision instrument makers (841-849): } \\
\text { Machinery fitters and machine }\end{array}$ & $\begin{array}{r}137 \\
22 \\
128\end{array}$ & $\begin{array}{r}229 \\
20 \\
229\end{array}$ & $\begin{array}{l}1.24(0.94-1.62) \\
2 \cdot 14(1.07-4 \cdot 31) \\
1.06(0.81-1.40)\end{array}$ & $\begin{array}{l}0.06 \\
0.02 \\
\text { NS }\end{array}$ \\
\hline $\begin{array}{l}\text { assemblers (841) } \\
\text { Motor vehicle mechanics (843) }\end{array}$ & $\begin{array}{l}49 \\
65\end{array}$ & $\begin{array}{l}89 \\
96\end{array}$ & $\begin{array}{l}1.03(0.68-1.58) \\
1.06(0.73-1.54)\end{array}$ & NS \\
\hline $\begin{array}{l}\text { Plumbers, welders, sheet metal and } \\
\text { structural metal preparers, } \\
\text { erectors (871-879): }\end{array}$ & 73 & 87 & $1.37(0.96-1.97)$ & 0.05 \\
\hline $\begin{array}{l}\text { Plumbers and pipe fitters (871) } \\
\text { Welders and flame-cutters (872) } \\
\text { Sheet metal workers (873) } \\
\text { Printers and related workers (921-929) } \\
\text { Transport equipment operators (981-989): } \\
\text { Motor vehicle drivers (985) }\end{array}$ & $\begin{array}{r}25 \\
18 \\
32 \\
32 \\
157 \\
128\end{array}$ & $\begin{array}{r}25 \\
23 \\
32 \\
51 \\
224 \\
167\end{array}$ & $\begin{array}{l}1.80(0.96-3.37) \\
1.42(0.79-2.88) \\
1.51(0.85-2.68) \\
1.15(0.68-1.93) \\
1.35(1.05-1.75) \\
1.42(1.07-1.89)\end{array}$ & $\begin{array}{l}0.04 \\
\text { NS } \\
0.08 \\
\text { NS } \\
0.01 \\
0.01\end{array}$ \\
\hline
\end{tabular}

*Adjusted for cigarette exposure. 


\section{Discussion}

In this study some results on the associations between lung cancer and occupations were consistent with those reported elsewhere. ${ }^{10}$ The use of arsenical insecticides by agricultural workers being frequent, the excess of lung cancer risk observed in our study $(R R=$ $1.24, p<0.06)$ is consistent with those previously reported." Arsenic, iron ore, asbestos, and uranium mining are recognised by IARC to present a risk of lung cancer. Although the type of mining was not recorded in this study, the risk of lung cancer was significantly increased for miners $(R R=2 \cdot 14)$. The significant excess of risk for motor vehicle drivers $(\mathrm{RR}=1.42, \mathrm{p}<0.01)$ has previously been related to polycyclic aromatic hydrocarbons. In the IARC's classification, however, hauliers are suspected but not recognised as having an increased risk of lung cancer.

Lastly, an excess of risk, although not significant, for the following suspected occupations was found: welders and flame cutters $(R R=1.42)$ and printers and related workers $(R R=1 \cdot 15)$. These non-significant results may be due to a lack of power in our study.

This case-control study was performed principally to study the effect of exposure to tobacco on the occurrence of lung cancer. This type of study is not the most suitable to evaluate the effects of occupational exposures on lung cancer since in most occupations there are few cases and controls. This probably explains the absence of significance of some associations, and the lack of a dose response relation with the duration of exposure in the case of significant associations. Despite these reservations, the results provide supplementary evidence of some occupational factors.

Although cigarette smoking is the major cause of lung cancer, several respiratory carcinogens have been discovered in studies of occupational groups. Further cohort studies are necessary, however, to establish the carcinogenic effect of certain occupational exposures on the lungs.

We thank the National Cancer Institute for its support and Dr E L Wynder for the implementation of the protocol. We are indebted to Drs R Arriagada, J P Bader, G Batesti, J Bignon, P Bilski-Pasquier, H Bismuth, C Blatrix, P Bouche, B Bour, C Boutin, J
Brissard, M Camey, I Caubarrere, J Chretien, D Chassagne, A Chavy, P Choubrac, A Cornet, B Court, J Courty, V Demassieux, G De Ren, N de Saint Florent, J Dormont, P Duroux, J Guedon, J P Kleisbauer, J Lacour, P Lamy, T Le Chevalier, G Lemoine, E Letournel, G Manigand, J Marsac, P Massias, G Mathe, A Monsaingeon, $\mathbf{P}$ Morin, $\mathbf{R}$ Pariente, C Perol, G Pierard, J Pointillard, J Rainaut, S Redon, J Rochemaure, J Sebaoun, D Silbert, C Sors, and $G$ Verges for their contributions to data.

Supported by Public Health Service Contract NO1CP-05642 from the Division of Cancer Cause and Prevention, National Cancer Institute.

Requests for reprints to: Simone Benhamou, INSERM U287, Institut Gustave Roussy, Rue Camille Desmoulins, 94805 Villejuif, Cedex.

\section{References}

1 Le Laidier S. Les consommateurs de boissons alcooliques et de tabac. Paris: Ministère des Affaires Sociales et de la Solidarité Nationale, 1984. (Solidarité Santé-Cahiers statistiques No 1.)

2 Fox AJ, Adelstein AM. Occupational mortality: work or way of life? J Epidem Commun Health 1978;32:73-8.

3 Doll R, Peto R. The causes of cancer. Quantitative estimates of avoidable risks of cancer in the United States today. Oxford: University Press, 1981.

4 International Agency for Research in Cancer. Monographs on the evaluation of carcinogenic risk of chemicals to humans. Vols 1 to 26. Lyon: IARC, 1972-1981.

5 Simonato L, Sarraci R. Cancer, occupational. In: Parmeggiano L, ed. Encyclopedia of occupational health and safety. Geneva: International Labour Office, 1983.

6 Lubin JH, Blot WJ, Berrino F, et al. Patterns of lung cancer risk according to type of cigarette smoked. Int $J$ Cancer 1984; 33:569-76.

7 Benhamou S, Benhamou E, Tirmarche M, Flamant R. Lung cancer and use of cigarettes: a French case-control study. JNCI 1985;74:1169-75.

8 International Labour Office. International standard classification of occupations. Genèva: ILO, 1968.

9 Breslow NE, Day NE. Statistical methods in cancer research. Vol 1. The analysis of case-control studies. Lyon: International Agency for Research on Cancer, 1980:32.

10 Fraumeni JF, Blot WJ. Lung and pleura. In: Schottenfeld D, Fraumeni JF, eds. Cancer epidemiology and prevention, London: W B Saunders Company, 1982:564-82.

11 Wang $\mathrm{HH}$, MacMahon B. Mortality of pesticide applicators. J Occup Med 1979;21:741-4. 